\title{
Research on the Business Model of Insurance Companies Developing the Old-Age Care Communities-Taking China Life as an Example
}

\author{
Lulu Shi, Yifeng Wang \\ School of Economics and Management, Xidian University, Xi'an, China \\ Email: lulucy619@163.com
}

How to cite this paper: Shi, L.L. and Wang, Y.F. (2018) Research on the Business Model of Insurance Companies Developing the Old-Age Care Communities-Taking China Life as an Example. American Journal of Industrial and Business Management, 8, 1928-1940. https://doi.org/10.4236/ajibm.2018.89129

Received: August 6, 2018

Accepted: September 8, 2018

Published: September 11, 2018

Copyright $\odot 2018$ by authors and Scientific Research Publishing Inc. This work is licensed under the Creative Commons Attribution International License (CC BY 4.0).

http://creativecommons.org/licenses/by/4.0/

\begin{abstract}
In recent years, Chinese population is tilted towards older people, and it is very limited for the state to invest in the elderly care facilities. Encouraged by the national policy, many insurance companies have embarked on constructing and operating the retirement community. However, the profit model of these insurance companies is not clear yet, and the return on investment is low, in which China Life is quite typical. Therefore, taking China Life as the research object and Osterwalder's nine-element theory as a tool, the paper analyzes the existing business model of China Life developing the old-age care communities, and uses the business model canvas to reconstruct a new business model. Finally, the paper presents three management suggestions-that is-joint ventures with professional management institutions, innovative insurance products linked to pension communities, and the securitization of old-age assets. That will provide references for other insurance companies developing old-age care communities.
\end{abstract}

\section{Keywords}

Insurance Company, Old-Age Care Community, Business Model,

Nine-Element Theory of Osterwalder's Business Model

\section{Introduction}

According to the National Statistics Yearbook, by the end of 2016, China's total population was about 1.383 billion, of which about 150 million were aged 65 and over, accounting for $10.8 \%$ [1], far greater than population aging standards of 
the United Nations-the population aged 65 years old and older accounts for 7\% of the total population, indicating that China is completely in an aging society. With the improvement of consumption levels and the change of fertility concepts, the elderly population in China will continue to grow at a faster rate, and the aging trend will increasingly intensify. It is estimated that by 2020, the number of elderly people over the age of 60 will increase to around 255 million and its proportion in the total population will increase to about 17.8\% [2]. All the data show that China's aging situation is extremely severe, and "let the elderly can be supported and have something to rely on" has become an important issue.

The increasingly severe aging situation has intensified the problem of old-age care. More and more elderly people have no choice but institution pension. However, because the facilities and services are not in place, the old people lives in an embarrassed life, even many institutions just hang the signs but there are few old people inside. At present, all major cities in China have built institutions such as nursing homes and old-age homes. The beds in public nursing homes are limited, while private nursing homes or old-age homes are expensive and the environment is very poor. Moreover, these nursing homes or old-age homes only meet the material and physiological needs of old-age people, but pay little attention to their spiritual needs and psychological comfort, which leads to deficiency of structural supply of the old-age institutions.

Encouraged by national policies, many insurance companies are eager to join the army of investing in the pension industry, especially in the development of the old-age care communities. Among them, China Life, as one of the top 500 listed insurance companies in the world, has abundant funds, cooperative relationships with medical institutions, strong customer resources and marketing networks, but lacks management experience in developing old-age care communities. In addition, the profit model is not clear, and poor operation results in low return on investment. If China Life can fully integrate resources and advantages, it will play a positive leading role in the development of China's old-age care communities.

Therefore, based on the nine-factor theory of business model, this paper analyzes the existing business model of China Life developing old-age care communities and reconstructs a new business model. Combined with the specific practice and nine structural blocks, it enriches the connotation of business model, and exports a new business model canvas for China Life developing old-age care communities, which can provide references for other insurance companies.

The content is organized as follows: the first section is introduction of background; the second section is a literature review on old-age care communities, the connection between old-age care communities and insurance companies, and the business model; taking China Life as an example, the third section analyzes the existing business model of developing old-age care communities; the fourth section reconstructs a new business model, and the last section gives a discussion of specific suggestions. 


\section{Literature Review}

\subsection{Old-age Care Communities}

The American pension community refers to the CCRC-Continuously Cares for the Retirement Community-is defined from an age perspective. The retirement community is a community that meets the needs of elderly people over the age of 50 who do not have children under the age of 18 . The residents of this community can enjoy daily life services, perfect care and leisure activities [3]. In the United States, there are three main modes of the old-age care communities: one is the full-time "retirement home" in which they can enjoy the comprehensive services and facilities in the community, and the second is the day-care "senile center" in which they takes part in community activities during the day and return to home at night, and the third is "mutual support for the elderly" in which the single elderly form pairs in the community to enjoy the life of old age [4]. The community generally refers to a social group of people within a specific geographical area. From the view of customer, the old-age care communities is a life group of the elderly living with managers or servers, and they buy or lease the property rights in the community in order to obtain an excellent old-age environment and services. This definition is used in the paper. In the old-age care communities, the elderly enjoy the perfect facilities and services, and the managers or servers can provide with high-quality services as much as possible, and the entire community is managed in a way of autonomy. This is different from pension real estate and pension institutions: pension real estate is included in the old-age care communities, and a single pension real estate cannot be called pension community [5]. Because it is just a building without residents or few residents, it is not enough to form a retirement community. However, only developing into a certain size, the community pension institutions can form an old-age care communities. Through sorting out many documents, the differences between the old-age care communities and community pension institutions are shown in Table 1.

The construction of the old-age care communities is of great significance for solving the problem of old-age care in China. Under the background of aging population, the fact that family pension and institutional pension cannot satisfy the needs of old-age care is becoming more and more prominent. Community pension, a novel old-age care mode, is gradually popular with and recognized by

Table 1. Differences between old-age care communities and pension institutions.

\begin{tabular}{ccc}
\hline & Old-age care communities & Community Pension Institutions \\
\hline $\begin{array}{c}\text { Purpose of } \\
\text { the establishment }\end{array}$ & $\begin{array}{l}\text { to provide a better old-age } \\
\text { environment and service }\end{array}$ & $\begin{array}{c}\text { to solve the daily care problem } \\
\text { of the inconvenient old people }\end{array}$ \\
Needs level focused on & material and spiritual & material \\
Established institution & investors & government \\
Profit property & profit-making & non-profit \\
\hline
\end{tabular}


the elderly. However, the development of China's old-age care communities is still at the primary stage and has little successful experience for references . There still exists many problems on developing old-age care communities in China. For example, the internal functions of the old-age care communities are not so perfect that the life quality of the elderly cannot be truly improved; the government provides little support and the relevant policy is ambiguous; lacking of the characteristic community pension model adapted to China's national conditions [6], and the shortage of funds has become major bottlenecks in developing community pension model.

\subsection{Connection between Insurance Companies and Old-Age Care Communities}

In view of the problems above, the connection between the insurance company and the old-age care communities can achieve a multi-faceted effect. The return rate of insurance companies on long-term investment in real estate is about $6.5 \%$, which is much higher than bank deposits and treasury yields and which is close to stock returns [7]. Therefore, insurance companies can consider investing a some percentage of real estate, which provides a basis for insurance companies to invest in old-age care communities. Insurance and pension industry are closely related. As for life insurance companies, the pension service industry can extend the insurance policy period to a certain extent and promote the potential value of the policy; while life insurance companies have a large amount of customer resources, which can supply the constant customers for the pension community [8]. By locking insurance policies and pension communities, life insurance companies can avoid the impact of inflation on insurance funds. On the other hand, the innovative design of insurance products also can play an important role in solving the problem of pension. In addition, life insurance companies have great advantages in reputation, finance, resource, etc. The old-age care communities can be regarded as a downstream industry most relevant to life insurance companies [9]. The benign connection between life insurance products and the old-age care communities can not only promote the extension of the company's main business chain, but also increase the return on investment of life insurance funds.

There are several major views on the forms of connection between insurance companies and the old-age care communities. Insurance companies invest in the construction of old-age care communities is not only to meet the basic material needs of the elderly, but also to pay more attention to their spiritual needs, therefore, they increase the construction of recreational facilities and treatment facilities in the community. From the perspective of insurance funds application and insurance product functions, it is an active exploration for Insurance companies to develop the old-age care communities. There are five modes for insurance companies to develop old-age care communities, namely, the whole capital mode, the equity cooperation mode, the equity investment mode, the REITs mode, and the mode of issuing real estate investment in fund products [10]. The 
first two are direct investments, and the latter three are indirect investments. American insurance companies develop pension communities mainly through REITs, including a net rental mode, a mandatory operation mode and a joint venture mode. However, when insurance companies conduct a portfolio, its yields and risks are positively related. The greater the risk, the higher the return on investment will be, and the regulatory costs and credit costs will also rise up. Therefore, while making investment plans, it is necessary for insurance companies to balance the relationship between yields, risks and costs [11]. At present, there are two operational modes for China's insurance companies developing pension communities. One is the heavy asset mode similar to commercialized retirement communities, under which insurance companies provide the comprehensive services of daily life, entertainment, social activities, nursing care, and medical treatment by investing in and operating old-age care communities. And the other is the asset-light mode, in which the insurance company entrusts a third party to provide care services for the elderly, such as professional caregivers to provide door-to-door care services.

\subsection{Business Model}

The concept of business model was first proposed in the 1950s and was widely spread in the business circles in the late 1990s.Until to today, the business model has still been what both academia and business focus on. Drucker, a world-class management guru, once said that the competition between enterprises is not the competition between products, but the competition between business models, which shows that the business model is of high importance. The academia has not yet formed a unified view on the business model. Johnson defines the business model as "a description that a specific business creates and delivers value to customers and businesses themselves" [12]; Osterwalder and Pigneur believe that "business model is the principle of how companies create value, deliver value and gain value" [13]. Li Zhenyong believes that the business model refers to "a solution that can maximize customer value and corporate profitability by fully integrating the various management methods and elements and building an effective and competitive system" [14].

In order to study the business model systematically, scholars at home and abroad have proposed different analytical tools and frameworks. Wang Shouyang et al. propose the iceberg theory of business model and the CET@I methodology used for analyzing the tacit knowledge of business models. The core idea is that the business model is a complex system that integrates with the organizational conditions including industry (C), regional environment (E) and technological development (T) [15]. Wei Wei and Zhu Wuxiang believe that the business model is essentially a transaction structure, and an organic business model system mainly covers six elements-positioning, business systems, key resources and capabilities, profit mode, free cash structure, and enterprise value [16]. They also emphasizes that the transaction structure of stakeholders can provide a comprehensive perspective for describing, adjusting and designing business 
models. Demil and Lecocq believe that the business model can be explained by the four key elements of revenue, cost, organization and value that called RCOV model [17]. Osterwalder and Pigneur present a nine-element theory of business model in the form of a canvas, which comprehensively analyzes the business model of the organization from four aspects-product or service, customer coverage, infrastructure and financial viability, and call the business model canvas as "a universal language used to describe business models, to visualize business models, to evaluate business models and to change business models" [13]. The nine-element theory of business model proposed by Osterwalder et al. is used for an analytical tool in this paper.

Osterwalder et al. proposed in Business Model Generation that "business model can be seen as nine blocks consisting of value proposition, customer segmentation, channel access, customer relationship, core resources, key business, important cooperation, cost structure, revenue sources." This paper attributes these elements to four dimensions-products or services, marketing strategy, resource management, and financial capabilities. Based on Osterwalder's description in the Business Model Generation, a brief description of the nine elements of the business model is shown in Table 2.

In summary, the current literature mainly focuses on the practical significance of insurance companies developing old-age care communities and the specific

Table 2. A brief description of the nine elements of the business model.

\begin{tabular}{|c|c|c|}
\hline Four Dimensions & Components & Brief Description \\
\hline Products or Services & $\begin{array}{c}\text { Value } \\
\text { Proposition }\end{array}$ & $\begin{array}{l}\text { The company provides a variety of optional } \\
\text { products or services for a specific group of } \\
\text { customers, seeking a resonance point to meet } \\
\text { the diverse and individual needs of customers. }\end{array}$ \\
\hline \multirow{3}{*}{ Marketing Strategy } & $\begin{array}{c}\text { Customer } \\
\text { Segmentation }\end{array}$ & $\begin{array}{l}\text { After identifying the target customer groups, } \\
\text { the company classifies the customer } \\
\text { according to certain conditions. }\end{array}$ \\
\hline & Channel Access & $\begin{array}{l}\text { The way that companies approach customers } \\
\text { and deliver value propositions to their customers. }\end{array}$ \\
\hline & $\begin{array}{l}\text { Customer } \\
\text { Relationships }\end{array}$ & $\begin{array}{l}\text { Companies need to maintain an appropriate } \\
\text { relationship with their customers to increase sales. }\end{array}$ \\
\hline \multirow{3}{*}{ Resource Management } & Core Resources & $\begin{array}{l}\text { Real assets, financial assets, intellectual assets } \\
\text { or human resources. }\end{array}$ \\
\hline & Key Businesses & $\begin{array}{l}\text { Which businesses are needed to support } \\
\text { company's value proposition, channel access, } \\
\text { customer relationships, and revenue sources. }\end{array}$ \\
\hline & $\begin{array}{l}\text { Important } \\
\text { Partnerships }\end{array}$ & $\begin{array}{l}\text { Companies create a range of partnerships } \\
\text { for value activities of clients needed. }\end{array}$ \\
\hline \multirow[t]{2}{*}{ Financial Capabilities } & Cost Structure & $\begin{array}{l}\text { The various cost distributions that companies } \\
\text { need to spend in order to operate a } \\
\text { business model efficiently. }\end{array}$ \\
\hline & Revenue Sources & Profit mode and the main source of profits. \\
\hline
\end{tabular}


mode of construction. It lacks systematic analysis and scientific advice on the business model. Therefore, taking Osterwalder's nine-element model as a tool and China Life as the research object, this paper systematically analyzes the existing business model of China Life developing old-age care communities, and establishes a more scientific business model.

\section{Analysis of the Existing Business Model of China Life Developing Old-Age Care Communities}

Through literature consulting and field observations, the existing business model of China Life developing old-age care communities is shown in Table 3.

It can be seen from Table 3 that China Life developing old-age care communities mainly relies on the sale of insurance products and the operation of the old-age care communities to achieve profitability, but ignoring the expansion of other value-added services in the old-age care communities. It can be found that there are three problems in the existing business model: first, the insurance companies lack relevant operation experience, and the management of the old-age care communities is not in place; second, the businesses and channels are single, and it is difficult to meet the diverse needs of customers and to increase the value of customers; third, the amount of funds used to invest in the

Table 3. Analysis of the existing business model.

\begin{tabular}{|c|c|c|}
\hline Four Dimensions & Components & Brief Analysis \\
\hline $\begin{array}{l}\text { Products or } \\
\text { Services }\end{array}$ & $\begin{array}{c}\text { Value } \\
\text { Proposition }\end{array}$ & $\begin{array}{l}\text { The "Policy + Entity" mode provides the health } \\
\text { services by connecting insurance products and } \\
\text { old-age care communities. }\end{array}$ \\
\hline \multirow{3}{*}{$\begin{array}{l}\text { Marketing } \\
\text { Strategy }\end{array}$} & $\begin{array}{c}\text { Customer } \\
\text { Segmentation }\end{array}$ & $\begin{array}{l}\text { It aims mainly at old people with higher } \\
\text { requirements for the old-age quality. }\end{array}$ \\
\hline & Channel Access & $\begin{array}{l}\text { The channel is mainly uses the business } \\
\text { outlets and agents to sell. }\end{array}$ \\
\hline & $\begin{array}{l}\text { Customer } \\
\text { Relationships }\end{array}$ & $\begin{array}{l}\text { Social reputation and providing pension consultants for } \\
\text { the elderly are used to maintain customer relationships. }\end{array}$ \\
\hline \multirow{3}{*}{$\begin{array}{c}\text { Resource } \\
\text { Management }\end{array}$} & Core Resources & $\begin{array}{l}\text { Steady insurance funds and pension community } \\
\text { entities provide a material basis for the stable } \\
\text { operation of the aged community. }\end{array}$ \\
\hline & Key Businesses & $\begin{array}{l}\text { It mainly sells insurance products linked to the old-age } \\
\text { care communities, and offers diversified care services } \\
\text { and professional medical services. }\end{array}$ \\
\hline & $\begin{array}{l}\text { Important } \\
\text { Partnerships }\end{array}$ & $\begin{array}{l}\text { Networks of partnerships with well-known medical } \\
\text { institutions has been established to provide advanced } \\
\text { medical treatment for the aged community. }\end{array}$ \\
\hline \multirow{2}{*}{$\begin{array}{l}\text { Financial } \\
\text { Ability }\end{array}$} & Cost Structure & $\begin{array}{l}\text { It is mainly composed of fixed cost } \\
\text { (equipment maintenance, salary) and variable cost } \\
\text { (operation management). }\end{array}$ \\
\hline & Revenue Sources & $\begin{array}{l}\text { It is from the fees of the purchasing insurance, } \\
\text { service fee, and the rental fee of the property. }\end{array}$ \\
\hline
\end{tabular}


old-age care communities is very large and the payback period is long, resulting in poor financial liquidity of insurance companies. A detailed analysis is as follows:

First, the management of the old-age care communities is not in place. Domestic insurance companies developed old-age care communities relatively late, and have not yet had successful business models and scientific management experience for references. Foreign countries and China's national conditions are different and cannot be "replicated" completely, which increases the difficulties for China Life to develop old-age care communities. Inside, wrong judgments on the macro policies issued, lack of professional management methods and unreasonable allocation of funds will make the old-age care communities more chaotic so that management costs rise; outside, the overall economic trend, the real estate bubble, and the tax policy will bring great pressures to the management of the old-age care communities invested by China Life. At present, the prospects of the pension market are still unclear, and the expenditure on operation and management has been consumed. With the number of old-age care communities increasing, China Life's expenditure will be more. If the mistakes occur to management, it is very easy to affect the profitability of the old-age care communities.

Second, it is difficult to achieve and enhance customer value. China Life developing old-age care communities cannot effectively satisfy the true value of customers. The first reason is high cost. Insurance companies must invest in building an old-age community. They need to buy land, to build houses, to introduce professional medical care institutions, and equipped with health care facilities. These capital costs have been consumed a lot before the formal operation of the old-age care communities, which has become the most important reason for the high price of the old-age care communities; second, the lack of management talents and experience makes property, personnel and facilities in the community is chaotic, which has caused a lot of inconvenience to the living people. If the management of the old-age care communities is outsourced to a professional agency, the annual fee will be also a large expenditure. Third, the price is relatively high. China Life developing old-age care communities targets customers to middle-income and high-income groups in the initial stage of operation. The entry fee alone is difficult for ordinary people to accept.

Third, the existing business model has a poor capital liquidity. China Life has faced a problem of poor capital liquidity in the process of developing an old-age care community. The main reason is that on the one hand, the funds invested by insurance companies in the old-age care communities is very large, occupying a considerable proportion of investable assets and making the proportion of diversified investment small so that the total cash flow revenue is low; on the other hand, the old-age real estate is greatly affected by the national poli$c y$, and it is difficult for internal managers to predict the trend in the short-term and to take the opportunities of investing so that a large amount of funds are faced with loss. In terms of the investment in the old-age care communities, the recovery time is long and liquidity risk is easy to occur. 


\section{New Business Model Design for China Life Developing Old-Age Care Communities}

Based on the problem of China Life developing old-age care communities and China Life's strategic layout-"great pension, great health, and great capital management", it is necessary to not only provide elderly care services for residents in the community, but also introduce the health management and asset management to meet their health care and financial needs. Because the idle funds held by the elderly are strongly hoped to maintain value. In addition, in order to realize the good wishes of learning in old ages and giving back to the society, it is imperative to develop skills training and other services. Only in this way can we better enhance customer value.

\subsection{Products or Services}

Developing a series of insurance products and services for old-age care, health management and asset management to meet the diverse needs of the elderly.

Value proposition: China Life should continue the "policy + entity" model-linking insurance products to the old-age care communities. The elderly can purchase the corresponding insurance products to obtain the eligibility of the old-age care communities, and insurance proceeds are used for enjoying the service in the community. However, it is not enough to provide old-age health services for the residents in the community. Their health care and financial needs should also be consideration so that the idle funds held by the elderly can be preserved and value-added.

\subsection{Marketing Strategy}

Through market research, identifying and segmenting target customers, and determining the best marketing channel to contact customers, and maintaining the relationships that can satisfy customers.

Customer segmentation: Based on life quality and physical health condition, China Life developing the old-age care communities can further subdivide customers and provide professional services according to their needs.

Channel access: In addition to business outlets and agent sales, China Life developing old-age care communities can actively seek other channels such as telephone or online sales, regular customers' recommendation, door-to-door service promotion, and cooperation with related companies.

Customer relationships: China Life can maintain the customer relationships in the old-age care communities by relying on the social reputation of China Life, equipping with healthy and financial advisors, organizing various activities, and training for management and service personnel.

\subsection{Resource Management}

Digging businesses with high relevance to the pension industry as much as possible, extending the industrial chain, and reaching a partnership with 
high-qualified stakeholders.

Core resources: Except for a steady stream of insurance funds and pension community entities, China Life developing the old-age care communities can also extend the pension industry chain, such as securitize assets and enhance the value of assets.

Key businesses: China Life developing the old-age care communities not only provides basic services such as pension service, insurance sales, medical treatment, but also expands value-added services such as health consultation and asset management, which can increase income sources and meet the diverse needs of the elderly.

Important partnerships: Due to the lack of health management business, asset management business and management experience, it is necessary to establish a network of medical institutions and to reach a long-term cooperation agreement with health consulting companies, asset management companies and operation institutions, thus improving the life quality of residents in the community.

\subsection{Financial Capability}

Expanding the business scope as much as possible to increase the revenue sources, while minimizing costs.

Cost structure: The cost of China Life developing the old-age care communities consists mainly of fixed cost (operation and management expenditure, equipment maintenance and repair expenses, personnel salary) and variable cost (operation and management fee).

Revenue sources: In addition to basic premium, meal fees, service fees and other income, they includes property rental income and the income of services such as health consultation and wealth management.

Based on the above and Osterwalder's business model canvas, the new business model is as shown in Figure 1.

It can be found from Figure 1 and Table 3 that the new business model of China Life developing old-age care communities has four changes compared with the existing business model: First, at the products or services level, health management and asset management have been added; Second, at the marketing strategy level, the scope of customer segments has been expanded, and the marketing methods and customer relationships maintenance have been enriched. Thirdly, at the resource management level, the scope of core resources and key businesses has been expanded, and the important cooperative network has been enriched. Fourth, at the level of financial capabilities, revenue sources have been increased.

\section{Conclusions and Suggestions}

Based on the nine-element theory of Osterwalder's business model, this paper analyzes the existing business model of China Life developing old-age care 


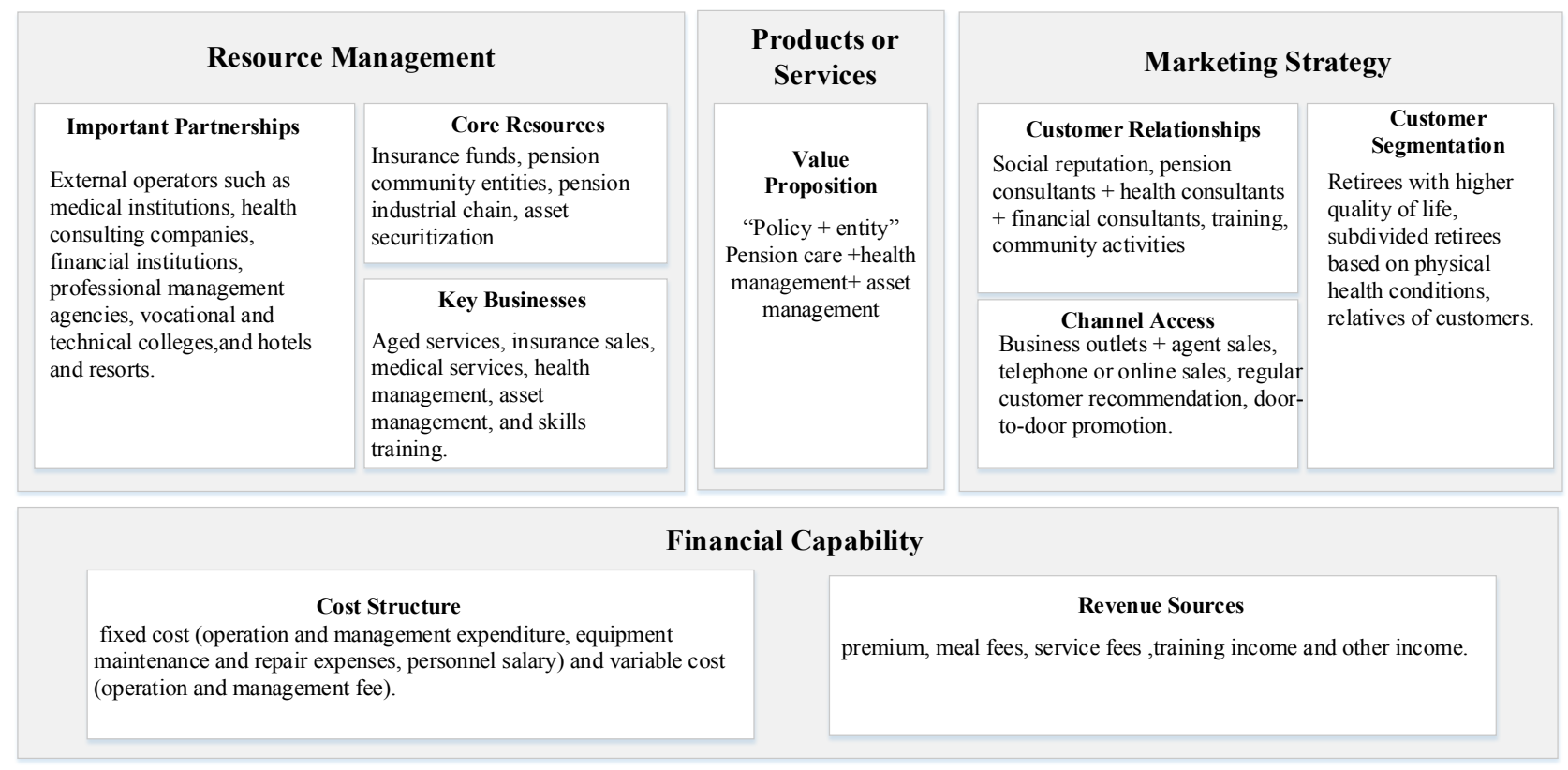

Figure 1. New business model design for China Life developing aged community.

communities. It is found that it mainly has three problems of inadequate management, difficulty in improving customer value and poor liquidity. Therefore, three suggestions can be put forward as follows:

First, China Life can collaborate with professional management institutions. China Life has sufficient financial advantages and a network of medical institutions, but it must also recognize that it has no experience in the aspect of operating and managing old-age care communities. In the early stage, China Life must invest a lot of money in the construction of the old-age care communities. But in order to reduce operational risks and improve the return on investment, joint venture with professional management institutions has become an inevitable choice. Relying on its advanced and scientific experience, the professional management institutions can provide professional services for old-age care communities, which can enhance customer satisfaction, attract more customers, and create sufficient conditions for profit acquisition.

Second, China Life can innovate the insurance products linked to the old-age care communities. Focusing on customer needs, China Life should continuously develop forward-looking financial derivatives linked to old-age care communities, which can help them manage their finances and ensure future life quality is not affected. For example, if a customer signs a contract or agreement with China Life, the person will have the right to stay in the future pension community in advance, and can receive the survival funds every year. After the expiration, they can either receive the birthday money and bonus or put all into the universal insurance account to obtain higher income, thus achieving the dual functions of both pension and finance. In addition, China Life's pension communities should provide thoughtful and professional services for the elderly, revealing love and care in the details. Therefore, these factors such as living comfort and safety, 
humanized facilities and cultural social relations are taken in consideration.

Third, China Life can securitize pension assets. China Life need to invest a large amount of funds in the early stage, but long-term return on investment makes profit acquisition so difficult that the net cash flow is sometimes negative. These problems are not beneficial to improve efficient use of capital and to expand reinvestment, so China Life must attach importance to asset securitization in the insurance field and enhance the liquidity of funds. As for the pension community projects that are expected to generate stable net cash flows, it is necessary to transform their income rights into liquid and tradable securities assets by the means of restructuring and enhancing credit.

There are still some new research directions. For example, scholars can select more advanced tools to analyze problems, and research the logic of value creation, value transmission and value acquisition on insurance companies developing old-age care communities.

\section{Conflicts of Interest}

The authors declare no conflicts of interest regarding the publication of this paper.

\section{References}

[1] China Statistical Yearbook, National Bureau of Statistics. http://www.stats.gov.cn/tjsj/ndsj/2017/indexch.htm

[2] Cracking the Problem of Pension, the Central Committee of the National Revolution Proposes to Set National or Industry Standards for Old-Age Services, Netease News. http://news.163.com/18/0228/21/DBOT11GQ000187VE.html

[3] Brayne, H. and Carr, H. (2003) Foreword by Allan Levy. Law for Social Workers. Oxford University Press.

[4] Bonera, M. (2010) How Are the Operators in the Tourism Industry Approaching the Virtual Channel. International Review of Business Research Papers, 6, 157-169.

[5] Ou, X.Z. and Zhao, X.N. (2003) Strategic Choice of Insurance Companies Investing in the Aged Community. Insurance Research, 1, 119-127.

[6] Liu, L.F. (2012) Problems and Countermeasures in the Development of the Aged Community. Macroeconomic Research, No. 1, 29-32, 66.

[7] Rockwood, K. and Song, X.W. (2005) A Global Clinical Measure of Fitness and Frailty in Elderly People. Canadian Medical Association Journal, 8-51. https://doi.org/10.1503/cmaj.050051

[8] Gao, W. (2013) Promoting the Development of China's Pension and Health Industry Clusters-Interview with Dai Wei, Chairman of Hezhong Life Insurance Co., Ltd. China Insurance News, 11, 2.

[9] Yan, Y. (2013) Analysis of the Development and Management Model of Old-age Commercial Real Estate Projects. People's Forum, 11.

[10] Zhang, P. and Mao, Q. (2013) Life Insurance Industry Intervenes in the Aged Industry: Experience and Realistic Choice. Southern Finance, 3, 79-82.

[11] Mueller, G.R. (1994) Should REITs Be Included in a Mixed-Assets Portfolio. Real Estate Finance, 11, 66-77. 
[12] Johnson, M. (2010) Seizing the White Space: Business Model Innovation for Growth and Renewal. Harvard Business School Press, Boston.

[13] Osterwalder, A. and Pigneur, Y. (2010) Business Model Generation: A Handbook for Visionaries, Game Changers, and Challengers. John Wiley \& Sons, Hoboken.

[14] Li, Z.Y. (2006) Business Model-The Highest Form of Enterprise Competition. Xinhua Press, Beijing, 3-4.

[15] Wang, S.Y., Qi, J.N., Qiao, W., et al. (2015) Business Model Iceberg Theory Based on Knowledge Management. Management Review, 6, 3-10.

[16] Wei, W., Zhu, W.X. and Lin, G.P. (2012) Business Model Theory Based on Stakeholder Transaction Structure. Management World, 12, 125-131.

[17] Demil, B. and Lecocq, X. (2010) Business Model Evolution: In Search of Dynamic Consistency. Long Range Planning, 2, 227-246.

https://doi.org/10.1016/j.lrp.2010.02.004 